LOQUENS 6(1)

January 2019, e059

eISSN 2386-2637

https://doi.org/10.3989/loquens.2019.059

\title{
Phonology and Writing: Can we look at written productions to "see the unseeable" in phonology?
}

\author{
João Veloso \\ University of Porto, Portugal (FCT - UID/LIN/0022/2016) \\ jveloso@letras.up.pt ORCID: https://orcid.org/0000-0002-5070-8838
}

Submitted: 05/01/2018; Accepted: 05/12/2018; Publicado online: 03/04/2019

Citation / Cómo citar este artículo: João Veloso. (2019). Phonology and Writing: Can we look at written productions to "see the unseeable" in phonology?. Loquens, 6(1), e059. https://doi.org/10.3989/loquens.2019.059

\begin{abstract}
Oral and written productions of language seem to correspond to ontologically separate entities. In this paper, we shall not argue against this basic assumption. However, it will be proposed that a careful examination of the writing systems and of particular written productions can provide phonologists with important information about the nature of phonological representations. Writing systems often originate in relevant intuitions about the nature of phonological units and phenomena and preserve the morphophonemic kinships between roots and words that are surfaced as phonetically distinct. The same can be said about the written productions of pre-school children and illiterate adults, strongly shaped by phonological intuitions rather than by orthographic convention. Bearing in mind that phonology, within the generative approach that is adopted here, is a form of knowledge, spelling can be accepted as a way of getting access to phonological knowledge. Therefore, our main point is that, in spite of the classical divide between spoken and written language, attention to writing can be useful for the understanding of the phonological level, too. The article includes two main parts: firstly, on Sections 2 and 3, we shall survey some general aspects of the relation between phonological and written representations; the second part consists mainly of Section 4 and attempts to illustrate some of the topics presented in Sections 2 and 3 with some data of a small-scale study with Portuguese pre-schoolers.
\end{abstract}

Keywords: phonological knowledge; literacy; writing systems; spelling; creative spelling.

RESUMEN: Fonología y escritura: ¿puede asumirse que las producciones escritas son 'habla visible' que permite ver lo invisible en fonología? - Las producciones lingüísticas orales y las escritas corresponden a entidades ontológicamente diferentes. En este artículo no presentaremos argumentos en contra de esta asunción básica. Sin embargo, se propondrá que un examen minucioso de los sistemas de escritura y de determinadas producciones escritas puede proporcionar a los fonólogos información relevante acerca de la naturaleza de las representaciones fonológicas. Los sistemas de escritura se originan a menudo a partir de valiosas intuiciones sobre la naturaleza de las unidades y los fenómenos fonológicos, y preservan las relaciones morfofonológicas entre las raíces y las palabras que se manifiestan en la superficie como fonéticamente distintas. Lo mismo puede afirmarse con respecto a las producciones escritas de los niños en edad preescolar y de los adultos iletrados, cuya forma está fuertemente condicionada por las intuiciones fonológicas más que por las convenciones ortográficas. Partiendo de la base de que la fonología, en el marco del enfoque generativista que se adopta aquí, es un modo de conocimiento, el deletreo constituye así una vía para acceder a ese conocimiento fonológico. Por consiguiente, nuestra conclusión principal es que, pese a la división entre lengua escrita y hablada, prestar atención a la escritura puede contribuir a un mejor conocimiento del nivel fonológico.

El artículo consta de dos partes principales: en las Secciones 2 y 3 repasamos algunos de los aspectos generales de la relación entre las representaciones fonológicas y las escritas; la segunda parte (Sección 4) intenta ilustrar algunos de los temas de las Secciones 2 y 3 con datos de un pequeño estudio con niños portugueses en edad preescolar.

Palabras clave: conocimiento fonológico; alfabetización; sistemas de escritura; deletreo. 


\section{INTRODUCTION}

Modern linguistics is grounded on a kind of interdictory warning that excludes writing from the scope of linguists' scientific interests.

Saussure's (1916) famous thoughts on the subject (which will be detailed in the following sections of this paper) not only contributed to mark the border between the oral and the written forms of language, it also banned writing from the scientific scope of linguistics among a substantial amount of researchers.

In this paper, we shall not argue against the assumption that the primary, intrinsic nature of language is to be found in its oral form. On the contrary, this is also a fundamental tenet of this study. Nevertheless, we shall try to demonstrate that written representations are not completely deprived of interest for the investigation about the nature, the form, and the contents of abstract linguistic representations. Our rationale, on this particular matter, is basically as follows: we assume phonology as part of the speakers' linguistic competence - of their "knowledge of language" / "I-language", in Chomsky's (1986) classical terms - and, therefore, the description of such form of knowledge as the main goal of phonologists (Burton-Roberts, Carr, \& Docherty, 2000, p. 2). For the description of the abstract form of knowledge that is the phonologists' explicandum, multiple evidence can be found in written productions and in some dimensions of the writing systems' organization, ranging from their history to some of their main structural properties. This is the main point to be developed in this article: How can the observation of written productions, and of writing systems underlying them, contribute to the development of what we know about speakers' phonological knowledge, hence about phonology and the phonological systems of particular languages?

In Section 2 of this paper, a review of the main arguments about the relationship between "language" and "writing" will be made. This will include a brief overview of some intrinsic properties of the main writing systems of the world, too. Section 3 will be devoted to the key question of our study: How can the study of given aspects of writing offer us substantial evidence on phonology? A review of some empirical findings, obtained among speakers of Portuguese and showing an actual example of the relation between knowledge of writing and phonological knowledge, will follow (Section 4). In the same section, an overall discussion of the several aspects analysed throughout the article will also be developed.

Even though we do not ignore the importance of other modalities of language and speech - namely, Sign Language - attention will be paid to spoken and written language only. The same can be said about the theoretical frameworks that will be taken into consideration here: given our main motivation-indeed, to show that written representations are not completely useless for phonological research-our review of the main arguments about this issue will focus on the two leading trends in modern descriptive linguistics, that is to say, the Structuralist and the Generative approaches according to their classical models. We acknowledge the existence of other approaches and, even within these two rather broad labels, of several divergent views. In spite of this, our attention will focus on the most current interpretations that are found in the earliest or in the most widely read texts of the leading authors of these two influential, yet traditional theoretical frameworks.

\section{LANGUAGE AND WRITING}

In this section, we shall focus on the common understanding, among many linguists and phonologists, between spoken language and writing. Such common view postulates that the very nature of language is to be found in its oral (spoken) realisations. Consequently, writing is regarded not only as a secondary but also as a non-intrinsically linguistic realisation of language itself. That is to say, according to the canonical understanding of this particular issue, not only oral and written representations differ in shape and in surface manifestations, they also correspond to two ontologically distinct entities. A drastic consequence of this strict divide is this: only oral language deserves the attention of linguistic science; writing, being a cultural, anthropological by-product of "true" language, does not have a place within the scientific scope of linguistics.

As Coulmas (2003) puts it, this is part of "linguistic orthodoxy", which finds its roots in the famous thoughts of Saussure (1916); see the following quotation, expressing a point of view shared by plenty of traditional linguists, such as Jespersen (1924, pp. 17-18), Bloomfield (1933, p. 21), Gleason Jr. (1955), or Martinet (1960, pp. 12-13), among others:

Language and writing are two distinct systems of signs; the second exists for the sole purpose of representing the first. The linguistic object is not both the written and the spoken forms of words; the spoken forms alone constitute the object (Saussure, 1959, p. 23; in Coulmas, 2003, p. 10).

According to this viewpoint, the only admitted relation between both "modalities" of realising speech has a hierarchical, deterministic nature: formal/structural properties of language(s) may be mirrored by written forms, but writing never (or almost never) influences linguistic structure. That is to say, the relation is strictly univocal

Figure 1: The relation between linguistic forms and written representations in the canonical linguistic perspective.

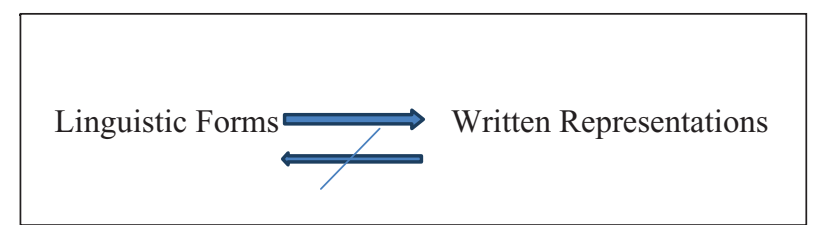


(spoken language $\rightarrow$ writing, never writing $\rightarrow$ spoken language), as we try to sketch out in Figure 1.

Insisting on Coulmas' (2003) view again, this onesense interference can be described in the following terms:

Although the obvious fact that languages change in the course of time is acknowledged, the possibility that their nature may be affected by external factors such as writing is strictly denied, allegedly on the grounds that writing could not possibly have exercised any influence on the faculty of language because it is too recent an invention (Coulmas, 2003, p. 10).

Since language is conceived as an essential part of human nature, while writing is a mere technology, the effects of writing on language and by implication the complexities of their interrelationship remain largely unexplored (Coulmas, 2003, p. 10).

The rare cases where the opposite direction of this relationship is attested are seen as abnormal: since writing is intrinsically non-linguistic, external and subsidiary to spoken language, the mere hypothesis of its exerting any influence over an entity which it is supposed to mirror rather than to shape is almost completely impossible. Within the different approach of generative grammar, language - conceived of as a biologically formatted faculty, largely independent of cultural variables and assumed as fundamentally the same endowment among all individuals of the human species (Chomsky, 1965) — should not therefore be shaped by any sociocultural, historical accident like writing (Chomsky, 1965, p. 3; 1975, pp. 12, 27, 30; 1978, pp. 200-201; 1986; 1988, pp. 2, 4, 9-10; Crain \& Fodor, 1993, p. 170; Pinker, 1994, p. 18).

It is beyond doubt that one of the primary forms of language is spoken language: oral realisations are intrinsically linguistic, contrarily to what happens with written forms. This is a classical standpoint of linguistics and the main arguments regarding this issue are summarised, among others, by Coulmas (2003, p. 11)—who, however, adopts a critical perspective on the categorical separation of both:

- historically, all languages began to be spoken and oral. The writing systems used to record it through visible signs are relatively recent, non-universal cultural artifacts. The fact that a spoken language cannot exist without its oral expression, but writing is optional and secondary, is, undoubtedly, a convincing evidence of the non-linguistic character of writing;

- $\quad$ indeed, until very recently, many spoken languages used to rely on their oral, spoken productions only;

- oral language is acquired informally, regardless of formal instruction, and within a naturalistic setting: "simple" exposure of children to their mother tongue(s) will trigger the acquisition of the particular grammars of such languages. By the contrary, learning the written code requires a precise cultural experienceschooling, literacy-, i.e., formal instruction, which is not universal and recruits a set of explicit cognitive resources that are not activated in L1 acquisition;
- speech is continuous in nature (as shown by the observation of a waveform or a spectrogram, without any intervals or categorical gaps between contiguous sounds), whereas writing is based on the explicit alignment of discrete, individual visual signs;

- oral languages are strictly governed by universal principles constraining their formal (phonological, morphological, syntactic, semantic) properties, whereas writing systems vary considerably across cultures and historical periods;

- oral languages are not subject to fiats or any other normative instruments. Differently, writing rules, in most modern societies, are often defined by explicit, arbitrary, conventional codes that are decided by institutions upon which society delegates the power to legislate on "orthography", to choose which alphabet should be adopted for the national language, to reform spelling rules, etc.;

- oral languages are subject to rapid change and considerable variation, whilst written forms are, by definition, rigidly fixed and change very seldom and very slowly.

These differences not only allow us to compare two distinct entities: they constitute clear evidence that spoken language and writing do correspond to two separate intrinsic objects, to two ontologically different realities. Needless to say, they strengthen the traditional perspective among linguists (not only phonologists) that writing is not, properly speaking, a true object of study of their discipline. Still according to such current viewpoint, writing is but a mere secondary representation, a by-product of "real" (= oral/spoken) language.

A reflection of this common view leads to the lack, in introductory books on general linguistics, of chapters specifically devoted to writing, as Coulmas (2003, p. 10) and Daniels (2010a, p. 43, 2010b) put it.

This apparent "downgrading" of writing is found among linguists, but this seems to be exclusive of the Western, Saussurean linguistic tradition: in the Eastern traditions, writing is a central piece of linguistic thought (Coulmas, 2003, p. 10; Daniels, 2010b). This view, by the other hand, contrasts with the social importance that is generally recognised to writing and its mastery. That is to say, linguistic "phonocentrism" is somehow contradicted to current sociocultural "graphocentrism", typical of modern, Western-like societies, where the importance of writing is over-rated, negative attitudes towards illiterate citizens are common, social organization strongly relies on written information, and common people tend to think of languages as written codes (Coulmas, 2003). Common sense about language structures and the nature of language, indeed, is strongly rooted in the awareness of the properties of writing systems: it becomes very apparent when we hear that "Hebrew has no vowels" (since the Hebrew abjad does not contain specific, segmental symbols for vowels; Rogers, 2005, p. 2) or when we teach phonetic transcription to beginner students (who very often are misled in their use of the International Phonetic Alphabet by the conventional writing), for instance. 
Isolating writing from linguistic study, in the terms that were summarised above, has not led, though, to its eradication as an object of study. This is demonstrated in several ways, which will be briefly referred to in the next following paragraphs.

\subsection{Linguistics and the organization of writing systems}

In spite of the apparent lack of interest towards writing found in many linguistic texts (see above), attempts were made by a few non-mainstream linguists to keep, to a certain extent at least, writing within the realm of linguistic inquiry. Among these attempts, we could cite here the work of graphematics, an under-represented subdiscipline developed during the Czech Structuralism era (see Sgall, 1987), which tried to apply to the study of writing systems the same principles and concepts used for linguistic analysis. This perspective was continued by other, more recent approaches, such as those found in the grammaticological work of Gelb (1952), in Linell's (1982) book and in the chapters of Luelsdorff (Ed., 1987). In addition to these approaches, we could also cite the work of Coulmas (2003), Rogers (2005) and Daniels (2010a), where the equation between spoken language and writing is thoroughly analysed.

Most of research within this line of thought has shown, though, that the organisation of formal grammars of spoken languages and the principles governing writing systems - mainly due to the most important differences between both, as summarised above-obey different rules and regularities. Formal properties of spoken languages and writing systems are indeed based on different types of units and relations.

\subsection{Intrinsic investigation of writing systems}

Indeed, a considerable amount of research on topics intrinsically related to the structural features of writing systems has been abundantly developed (for comprehensive reviews of this kind of research, see, e.g., Coulmas, 2003; Daniels, 1992; 2010a; 2010b; Février, 1984, and Rogers, 2005).

Among the most important findings related to the nature of writing systems, the kind of linguistic units that are embedded by the graphic signs found in different writing systems worldwide is a matter of major importance for our study. The observation of this issue allows us to get a typology of the main types of writing systems found in the world, which can be categorised, according to Daniels (2010a, p. 43), in five dominant groups:

1) Logosyllabaries/morphosyllabaries. These are systems where one sign roughly stands for one morpheme. As they are often used for writing languages with poor inflection and a high frequency of morphologically simple, monosyllabic words, syllables and morphemes tend to overlap. Very often, the phonetic value of a monosyllabic character expands itself to homophonic syllables.

2) Pure syllabaries. Such systems make one sign the graphic counterpart of one syllable (sometimes, of one mora), regardless of the morpholexical/ semantic value of such syllables and keeping unambiguous distinctions between monosyllabic words as systematically as possible.

3) Abjads (also known as Semitic writing systems). In abjads, written symbols transcribe consonants only. These are very common for writing Semitic languages, morphologically and lexically constructed over large repertoires of "triliterate" (=trisyllabic) roots where consonants play the main role regarding lexical distinctions: therefore, vowels, being easily predicted by context, do not need graphic notation.

4) Alphabets. Alphabetic systems contain letters that stand for both consonants and vowels. They seem to have originated in the Greek alphabet (in turn, built upon the Phoenician abjad), and they were first preferred to transcribe Indo-European languages, where lexical distinctions rely both in consonantal and vocalic pairs, making consonants and vowels equally unpredictable from context (thus, mandatorily recorded by written symbols).

5) Abugidas. These writing systems, combining properties of abjads and alphabets, have symbols that generally represent a syllable formed by a consonant and the unmarked vowel of the language. If the consonant is followed, in the same syllable, by a marked vowel, then different symbols (one for the consonant, another one for the vowel) are used. Devanagari, nowadays used for many Indic languages (either Indo-Aryan or Dravidian), is a good example of this kind of writing.

6) Featural systems. These systems are formed by a set of symbols (either consonantal or vocalic) that can be decomposed in the phonetic (articulatory) features that are found in the corresponding phonemes. Each symbol, therefore, combines a superimposed bundle of recurrent visual patterns, giving explicit information about the phonetic properties of the sound it transcribes (such as voicing, nasality, lip-rounding, etc.). Hangeul, used for transcribing Korean, is currently the most widespread of these systems. Although it was never officially adopted for the current writing of any language, Alexander Melville Bell's "Visible Speech"-a system of transcribing speech sounds idealised in the 19th century by one of the precursors of modern phonetics in order to help deaf people to understand spoken language - can also be considered a featural system (Coulmas, 2003, p. 30), since its basic design was grounded on the objective of visually registering, in separate dimensions of the written symbols, the different articulatory gestures underlying the production of a given speech sound. 


\subsection{Psycholinguistic approaches to writing systems}

Contrasting with descriptive linguists (focussed on the formal properties of language), psycholinguists, primarily concerned with aspects related to language processing and language learning, never refused so strongly the importance of writing.

This reflects a common understanding in this discipline, shared, for instance by Kavanagh (Ed., 1991), or Olson (1993), who insist on a continuum between oral and written language).

Most of the interest of psycholinguistics towards the relationship between oral and written language is motivated by experimental results that show that language processing differs between literate and illiterate subjects or when linguistic stimuli are presented orally or in written form, either in experiments dealing with speech perception (Frost, Repp, \& Katz, 1988; Hallé, Chéreau, \& Segui, 2000) or lexical recognition (Dijkstra, Grainger, \& van Heuven, 1999; Dijkstra, Timmermans, \& Schriefers, 2000; Grainger, Spinelli, \& Ferrand, 2000; Jared, 1997; Peereman \& Content, 1997; Zuck, 1996).

One of the main results in this domain is that phonemic awareness - the awareness that syllables can be broken into their ultimate segmental constituents, that is to say, consonants and vowels, and the capacity of deliberately manipulating such units (in experimental tasks like segmentation, deletion, inversion, etc.) - is exclusive of literate subjects who have been educated within an alphabetic system. Ontogenetically, it could be seen, therefore, as an "epiphenomenon", as Faber (1990) puts it. Illiterates or literate subjects who can write and read in any other writing system can perform very well in syllabic tasks, but are generally unable to perform segmental operations and do not show any clear signs of phonemic awareness (Alegria \& Morais, 1979; Alegria, Pignot, \& Morais, 1982; Content, 1985; Morais, Alegria, \& Content, 1987; Morais, Cary, Alegria, \& Bertelson, 1979; Morais, Kolinsky, \& Nakamura, 1996; Nakamura, Kolinsky, Spagnoletti, \& Morais, 1998; Scliar-Cabral, Morais, Nepomuceno, \& Kolinsky, 1997; Taylor, 2002).

\section{WRITTEN LANGUAGE AS A MEANS TO REACH PHONOLOGICAL REPRESENTATIONS}

In this section, we will address the central question of our study: how, despite the assumption that spoken language and writing correspond to different entities and are basically studied by different disciplines, our knowledge of writing can illuminate our understanding of specific aspects of phonology.

As we briefly sketched out in Section 1, phonology is assumed here as part of the abstract I-language that constitutes the very object of study of linguistics. Consequently, phonology deals with an abstract form of knowledge (Burton-Roberts, Carr, \& Docherty, 2000). As it happens with all disciplines that study non-empirical objects, ${ }^{1}$ descriptive phonology has to find a way to reach its empirically unattainable units and phenomena, the abstract phonological representations that are embedded in speakers' minds as part of their I-language (i.e., their "phonological knowledge", according to Burton-Roberts, Carr, \& Docherty, 2000, p. 2ff.; see also Berman, 1983, pp. 228, 231; Foss \& Hakes, 1978, p. 20; Foster-Cohen, 1999, pp. 1-3, 8, 183).

In some previous studies in which we also addressed this specific question (Miranda \& Veloso, 2017; Veloso, $2005,2007,2010)$, we have identified three possible ways to provide phonologists with a sort of "inferential access" to phonological knowledge:

- phonetic productions: if linguistic performance is governed by the abstract principles of internal grammar, then the actual phonetic realisations effectively produced by human phonatory apparatuses have to reflect such abstract principles. A careful examination of phonetic data, then, can be a way of extracting grammatical information about the underlying system that rules out actual speech products as linguistic manifestations. A limitation of this approach is that, as highlighted by authors such as Chomsky (1957, pp. 129-131; 1965, p. 4), Villiers and Villiers (1978, p. 5), Harris (1992, p. 2), and Foster-Cohen (1999, p. 10), performance can never be taken as an absolutely faithful mirror of linguistic competence, and calculating a deviation between both becomes a basic precaution.

- metaphonological abilities: in domains such as syntax, grammaticality explicit judgments are often elicited as usual ways of getting access to the internal speakers' grammars since it is assumed that they have the power to make implicit principles explicit. Likewise, in phonology, eliciting explicit manipulations of phonological data, which leads speakers to treat phonology as an "opaque" object per se, not just as a "transparent" means of making phonetic signs possible, is a way of indirect observation of the speakers' internal phonology (Berthoud-Papandropoulou, 1980, p. 2; Brédart \& Rondal, 1982, p. 9; Cazden, 1976, p. 603; Edwards \& Kirkpatrick, 1999, pp. 313-314; Gombert, 1990, pp. 13ff., 20; Pratt \& Grieve, 1984, p. 2; Read, 1978, p. 65; Tunmer \& Herriman, 1984, p. 12; Tunmer, Pratt, \& Herriman, 1984, p. vii; Van Kleeck, 1982, p. 237).

- written productions: finally, written productionswhich are central in this paper-can also be accepted, under certain circumstances, as a very specific type of linguistic performance on which many generalisations about phonology can be based. Not all written productions are useful for this purpose, though: canonical writing in modern literate societies and individuals, strictly governed by arbitrary, conventional rules that are culturally transmitted through schooling, fundamentally show how proficient subjects are

\footnotetext{
This is a classical problem for any cognitive science: see, for instance, Eysenck's (1994, p. 3) remarks about the methodological problems related to how psychologists get access to the human mind.
} 
in absorbing the awareness and conscious knowledge of such rules as a result of literacy. The written productions that seem to be more useful for us to get inferential access to phonological knowledge are those who are genuinely shaped by the speakers'/ writers' phonological intuitions, deeply rooted in their internal phonological knowledge rather independently of cultural constraints. Among these productions, special importance should be given:

- phylogenetically, to the early written productions of humankind (prior to orthographic constraints).

- ontogenetically, to children's early productions, as well as to illiterates' or poorly literates' productions. These productions, classified by Kress (2000) as "creative spellings" (by opposition to canonical, non-creative spellings), are assumed to reflect quite faithfully the individuals' phonological knowledge, not the knowledge of spelling rules (completely or poorly unknown among these particular speakers).

The "external" manifestations of phonological knowledge to be found in creative spellings are, as previously mentioned, the most important for the sake of the present study: it is our aim to demonstrate how observing writing - a "visible" form of speech - one can make generalisations about the "invisible" phonology of languages, as also assumed by previous research. Additionally, we shall also admit that other forms of writing which are not purely idiosyncraticas the main regularities that govern writing systems in general, ranging from the motivations that led to the creation of the earliest writing systems of the world to the fundamental features of current systems presently at use (partially comprehended by the "phylogenetic" dimension referred to above) - can also give us relevant phonological information.

These two instances of phonological relevance of writing manifestations - (1) non-canonical written forms by illiterate or poorly literate subjects, and (2) fundamental properties of established writing systems - will be analysed separately. In Sections 3.1 and 4, our attention will focus on the phonological information that can be collected from the observation of individual, non-canonical written productions. This survey will also show how literacy may arguably change the internal phonology of speakers. Section 3.2 will draw our attention to the inferences about phonological organisation that can be given by the observation of the principal features that govern the writing systems of the world throughout history.

\subsection{Non-canonical individual written forms and phonological knowledge}

Transposing speech continua to written chains is a cognitive activity that, in a highly literate subject, recruits his/her "orthographic lexicon" (Bates et al., 2007; Frost, 1989; Kohnen, Nickels, Coltheart, \& Brundson, 2008): regardless of their phonetic perception of the words and, to a certain extent, of their stored phonological representations, spellers retrieve their stored visual images of written words and reproduce them. This explains, for instance, writing in languages whose writing systems are not phonetic-phonological in nature (like the logographic systems) or have a distant relation with the phonetic/phonological shape of words. For someone who is writing English, for instance, assigning $<\mathrm{i}>$ (or $<$ igh $>$ ) to [ar] (as in $<$ high $>,<$ fight $>$ or $<$ five $>$ ) or to [I] (as in $<$ fit $>$, $<$ sit $>$, $<$ in $>$ ) is only possible through memorisation of individual letter-sound correspondences. When writers build their written forms on their own auditory analysis and phonetic perception of speech, more transparent, regular sound-letter correspondences can be expected. This is the case for the children's earliest written productions: when trying to spell, children not sufficiently familiar with the canonical spelling rules of the language follow their own phonetic and phonological analysis of speech (to put it very simply, following the same path as a phonetician doing phonetic transcription-see, among others, Booij, 1987, p. 215; Chomsky \& Halle, 1968, p. 49; Perfetti, 1997, pp. 35ff.). Therefore, what the pedagogical tradition classifies (and punishes) as misspellings might become a precious source for us to get access to the internal speakers' phonological representations (Miranda \& Veloso, 2017, among others).

The spelling of non-homographic homophones, as the examples found in Miranda \& Veloso (2017) show us, are a good illustration of this: in Portuguese, $<_{\mathrm{S}}>$ and $<_{\mathrm{Z}}>$ can have the same phonetic value. Different words such as coser 'to sew' [ku'zer] and cozer 'to boil' [ku'zer] are perfect homophones that are often confused in writing and can be interpreted as an overlapping of the phonological representations of both: when one spells one in the place of the other, s/he is showing that, in their internal phonology, the same phoneme $/ \mathbf{z} /$ is produced on the onset of the stressed syllable, regardless of the graphic distinctions that are mandatory only at the orthographic level.

In their classic study about the early internal representations of writing in their relation to linguistic representations, Ferreiro \& Teberosky (1984) showed that pre-schoolers can produce written "creative" forms that establish steady relationships with the units of the grammar: in a very early stage, visual signs are given as counterparts of words (as the ancient logographic systems did many centuries ago); later on, children refine their linguistic analysis and produce visual signs that are produced as representations of syllables (once again, as the ancient syllabaries, historically "younger" than the primitive logographic systems, did). This kind of writing data seem sufficient to allow a phonologist to assume that the units word and syllable are somehow represented in the children's internal linguistic knowledge.

\subsection{Fundamental properties of writing systems and phonological information}

The type of evidence provided by the individual written productions that were mentioned in Section 3.1 are often explored in psycholinguistic research in order to observe the internal organisation of individual grammars and their functioning in language processing, especially in processes involving language learning/acquisition or language impairments. Looking at the present form of 
writing systems, other conclusions about their phonological organization can also be drawn. According to a common categorisation of writing systems restricted to languages alphabetically written, it is possible to split languages into two different groups (Aaron, 1989, pp. 379ff.; Alcock \& Ngorosho, 2003, pp. 635ff.; Frost, 1989; Goswami, Ziegler, Dalton, \& Schneider, 2003; Leong \& M. Joshi, 1997, pp. 1ff.; Luelsdorff, 1991, p. 1; Reitsma, 1989, pp. 51ff.; Sgall, 1987, p. 1; Wimmer \& Landerl, 1997): languages with a transparent writing (i.e., languages in which the letter-sound relation is roughly stable in the sense that one letter has just one phonetic value and a sound is always written with the same letter of the alphabet, with as few exceptions as possible) $v s$. languages with an opaque writing (languages in which one single letter can have a myriad phonetic values and vice versa, that is, a given sound can be spelt with different letters of the alphabet). It should be borne in mind that no language fits definitely in one or another of these two groups: most languages mix up characteristics of both transparent and opaque systems (see, e.g., Aaron, 1989, p. 379)

Table 1 compares some languages on the basis of this rough distinction.

Table 1: Examples of languages with transparent vs. opaque alphabetic writing systems.

\begin{tabular}{ll}
\hline Languages with transparent alphabetic writing systems & Languages with opaque alphabetic writing systems \\
\hline DUTCH & ENGLISH \\
Booij, 1987, p. 215 & Fijalkow, 1982, p. 67 \\
Reitsma, 1989, p. 52 & Sgall, 1987, p. 1 \\
FINNISH & Snowling, 1989, p. 1 \\
Fijalkow, 1982, p. 67 & Luelsdorff, 1991, p. 1 \\
Reitsma, 1989, p. 51 & Leong and M. Joshi, 1997, p. 3 \\
Korkeamäki, 1997, p. 331 & Perfetti, 1997, p. 25 \\
Suomi and Ylitalo, 2004, p. 36 & Alcock and Ngorosho, 2003, p. 635 \\
GERMAN & Goswami et al., 2003, p. 236 \\
Valtin, 1989, p. 119 & FRENCH \\
Wimmer and Landerl, 1997 & Fijalkow, 1982, p. 67 \\
Wimmer, Landerl, and Frith, 1999 & Sgall, 1987, p. 1 \\
Goswami et al., 2003, p. 236 & Klees, 1989, p. 137 \\
\end{tabular}

\section{GREEK}

Porpodas, 1989, pp. 179ff.

Harris and Giannouli, 1999

Goswami et al., 2003, p. 236

\section{ITALIAN}

Fijalkow, 1982, p. 67

Morchio, Ott, and Pesenti, 1989, p. 143

Reitsma, 1989, p. 51

Leong and M. Joshi, 1997, p. 2

Perfetti, 1997, p. 25

Goswami et al., 2003, p. 236

\section{POLISH}

Sgall, 1987, p. 1

\section{PORTUGUESE}

Girolami-Boulinier and Pinto, 1996, p. 38

Leong and M. Joshi, 1997, p. 2

Alcock and Ngorosho, 2003, p. 635

\section{SERBO-CROATIAN}

Reitsma, 1989, p. 51

\section{SPANISH}

Fijalkow, 1982, p. 67

Sgall, 1987, p. 1

Valle-Arroyo, 1989, pp. $165 \mathrm{ff}$.

Leong and M. Joshi, 1997, p. 2

Goswami et al., 2003, p. 236

\section{TURKISH}

Çapan, 1989, pp. 192ff. 
What is important for the central issue that is discussed here is that languages with opaque systems tend to preserve etymological and historical forms of the words. A careful analysis of their writing systems can be very insightful for diachronic phonology to hypothesise about the old phonetic forms of the words of the language. Languages with transparent writing systems, which typically underwent several spelling reforms, tend to keep a written record of other type of important linguistic information: morphophonemic representations, morphological relations between roots and word forms, phonological processes (e.g., assimilations, harmonisation, segment insertion or deletion, etc.). Bearing in mind the type of linguistic structures, units, and relations that are kept (or unkept) by these two main different kinds of writing systems, we can draw some conclusions, too, about the nature of the phonological organisation of the languages in which they are used. Phonologists like Chomsky and Halle (1968, pp. 40, 48, 49, 80, 131) and Klima (1972, pp. 57ff.) recognise this, for instance, when the former acknowledge that the keeping of a written $<\mathrm{a}>$ in the English written pair profane/profanity (where $<\mathrm{a}>$ stands for [eI] and [æ], respectively) is a hint for the recognition of the same underlying representation of $[\mathrm{eI}]$ and $[æ]$ within the pair.

In European Portuguese, we can find a productive set of similar cases in the morpholexical pairs where the same root occurs in stressed and unstressed position: in the cases where it is stressed, the root vowel tends to be open; reduction to a close vowel is systematically found as a result of stress-lacking, as shown in Table 2. Instead of assigning to different phonetic quality of vowels different letter symbols, canonical orthography maintains, both for the stressed/open and the unstressed/close vowel, the same symbol, which can be interpreted as a sign that the orthographers of the language were aware of the morphophonemic kinship of both vowels and the relationship established within such pairs. We can say, thus, that the Portuguese writing system preserves quite well the morphophonemic level and, for phonologists studying the language, written forms can offer valid information about this level of Portuguese phonological representations. In

Table 2: Portuguese roots alternating in stressed (open vowel) $v s$. unstressed position ( $\mathrm{mid} /$ close vowel).

\begin{tabular}{|c|c|c|}
\hline Root & Stressed & Unstressed \\
\hline cas- 'house' & $\begin{array}{l}\text { casa 'house' } \\
\text { ['kaze] }\end{array}$ & $\begin{array}{l}\text { casinha 'small house' } \\
\text { [ke'zije] }\end{array}$ \\
\hline febr- 'fever' & $\begin{array}{l}\text { febre 'fever' } \\
\text { ['febrì ] }\end{array}$ & $\begin{array}{l}\text { febril 'feverish' } \\
\text { [fi'brił] }\end{array}$ \\
\hline med- 'fear' & $\begin{array}{l}\text { medo 'fear' } \\
\text { ['medu] }\end{array}$ & $\begin{array}{l}\text { medroso 'fearful' } \\
\text { [mi'drozu] }\end{array}$ \\
\hline port- 'door' & $\begin{array}{l}\text { porta 'door' } \\
\text { ['porte] }\end{array}$ & $\begin{array}{l}\text { porteiro 'doorman' } \\
\text { [pur'tejru] }\end{array}$ \\
\hline nov- 'new' & $\begin{array}{l}\text { novo 'new' } \\
\text { ['novu] }\end{array}$ & $\begin{array}{l}\text { novidade 'novelty' } \\
\text { [nuvi'dadi] }\end{array}$ \\
\hline
\end{tabular}

our view, this is another example of how the writing system of a language, even though it is an intrinsically nonlinguistic object of study and analysis, can be very useful for phonological analysis.

\section{AN EMPIRICAL STUDY AND SOME REMARKS}

In the previous sections, we explored the way in which the phonological properties of a spoken language can influence its writing system. This is a common assumption among linguists. The possibility of reconstructing past stages or phonological abstract representations of a spoken language on the basis of written forms, as explored in the previous sections, does not conflict with the current understanding among most linguists and phonologists according to whom spoken language and writing are rather independent and, what is more, the latter is a "mirror" of the former. In this section, we shall look at the opposite direction of this relation: how can the properties of a writing system have an impact on phonology itself?

In the following paragraphs, we shall present the results obtained with a group of Portuguese children who are learning how to write and read in their language. We observed how they explicitly manipulated words containing $\{\mathrm{S} \wp$ Obstruents $\}$ word-medial clusters. $/ \mathrm{S} /$, an underspecified coronal fricative, when occurring word-medially, can be licensed as the coda of the syllable at its left or as the onset of the syllable at its right. Many explanations for this variation have been proposed and discussed since the first orthographic treatises of the language (Leão, 1576 [1983]): due to the particular phonotactic behavior of coronal fricatives across a huge number of languages of the world (see, e.g., Kaye, 1992), words such as festa 'party' are explicitly split as fes.ta or fe.sta (the latter in violation of the Sonority Principle and the Dissimilarity Condition, as it often happens in other phonotactic environments of Portuguesesee Henriques, 2013, for instance). The conventional rules that govern written line-breaking in Portuguese impose that all line-breakings coincide with syllable boundaries; as for the specific cases where $\{\mathrm{S} \wp \mathrm{Obstruent}\}$ is found word-medially, it is postulated that these words be broken according to the mandatory pattern of letting $<_{\mathrm{S}}>$ in the first line (assuming it as the written counterpart of the first syllable's coda) and the following obstruent at the beginning of the following line (assuming it as the onset of the second syllable).

In our study, a group of 42 children, monolingual native speakers of European Portuguese (21 boys +21 girls) was followed in a longitudinal study during their 2 first years of schooling (mean age at first observation $=6 ; 11$ years old, $\mathrm{SD}=0 ; 4$ years; mean age at the last observation $=7 ; 11$ years old, $\mathrm{SD}=0 ; 4$ years). Children were explicitly asked to split words with a medial \{S §O Obstruent\} (see words in Table 3).

At the end of the first year of schooling-before children were formally taught the line-breaking rules of written words - the results shown in the explicit syllable breaking task were as shown in Table 4. 
Table 3: Words included in the test of explicit syllabic breaking.

\begin{tabular}{|c|c|c|}
\hline Word & $\begin{array}{l}\text { Phonetic transcription of the stimuli, with } \\
\text { the canonical syllable-breaking }\end{array}$ & $\begin{array}{l}\text { Canonical (mandatory) line-breaking of the } \\
\text { written forms corresponding to these words }\end{array}$ \\
\hline ginástica 'gymnastics' & [3i.'naJ.ti.ke] & gi-nás-ti-ca \\
\hline mosca 'fly' & ['mof.ke] & mos-ca \\
\hline floresta 'forest' & [flu.'ref.te] & flo-res-ta \\
\hline rasga 'strips' & ['Raz.ge] & ras-ga \\
\hline cesto 'basket' & ['se $\left.\int . t u\right]$ & ces-to \\
\hline
\end{tabular}

Table 4: Explicit syllable breakings found at the end of the first year of schooling.

\begin{tabular}{lcccc}
\hline \multicolumn{2}{l}{$\begin{array}{l}\text { N.SC/ SYLLABLE } \\
\text { BREAKINGS }\end{array}$} & $\begin{array}{r}\text { /VS.C/ SYLLABLE } \\
\text { BREAKINGS }\end{array}$ & TOTAL \\
\hline $\mathrm{N}$ & $\%$ & $\mathrm{~N}$ & $\%$ & $\mathrm{~N}$ \\
102 & 53.1 & 90 & 46.9 & 192 \\
\hline
\end{tabular}

Table 5: Explicit syllable breakings found at the end of the second year of schooling.

\begin{tabular}{lcccc}
\hline $\begin{array}{l}\text { V.SC/ SYLLABLE } \\
\text { BREAKINGS }\end{array}$ & \multicolumn{2}{c}{ /VS.C/ SYLLABLE } \\
\hline $\mathrm{N}$ & \multicolumn{2}{c}{ BREAKINGS } & TOTAL \\
35 & 17.5 & $\mathrm{~N}$ & $\%$ & $\mathrm{~N}$ \\
& 165 & 82.5 & 200 \\
\hline
\end{tabular}

Results show a division of these consonantal sequences almost at chance level, suggesting that children's phonological representations still lack a clear parametrisation of the internal phonotactics of these structures of Portuguese.

One year later, the same children show a clear shift in their responses: /VS.C/ breakings, in accordance to the mandatory written line-breaking rules that are intensively taught during their second year of primary school, are clearly prevalent, as shown in Table 5 . The differences between the results of first and second year are statistically significant (Wilcoxon test: $z=2.179 ; p<0.05$ ).

This shift - from a stage of the children's phonological knowledge where $\{\mathrm{S} \wp$ Obstruent $\}$ does not seem to have a clear prosodic representation towards a stage where they are prosodised in strict accordance with the orthographic rules that govern written line-breaking - is interpreted as a result of schooling: indeed, it is during the second year of primary school that Portuguese children are intensively exposed to formal instruction of such rules and, in our view, it could explain the observed change.

The importance of these results has to do with the strong suggestion that, as it happens with the development of phoneme awareness (commonly accepted as a result of literacy, too; see Section 2), it seems possible to alter some parameters of phonological representations via the written forms and the contact of subjects with writing. That is to say, spoken language and writing, though being different in nature and mutually extrinsical, can be closely related in many aspects. More importantly, and contrarily to what is generally assumed by most mainstream phonologists and linguists in general, not only language properties shape the written forms: the latter can also determine aspects of the subjects' phonology, as suggested by the results that are referred to in this section.

For a phonologist, then, looking at written representations and at the way they are learnt and processed by different cultures and individuals can lead to important conclusions that otherwise would remain out of reach. In other terms, when confronted with the difficulty of making the invisible phonology visible, phonologists can rely, even if limitedly, on the "visible speech" embedded in written forms to collect reliable information about their explicandum. Even if accepting the intrinsical, ontological distinction between both forms of realising speech and language, a bridge between both proves fruitful for our understanding of the abstract nature of phonology.

\section{REFERENCES}

Aaron, P. G. (1989). Orthographic systems and developmental dyslexia: A reformulation of the syndrome. In P. G. Aaron \& R. M. Joshi (Eds.), Reading and writing disorders in different orthographic systems (pp. 379-400). Dordrecht: Kluwer. https://doi.org/10.1007/978-94-009-1041-6 22

Alcock, K. J., \& Ngorosho, D. (2003). Learning to spell a regularly spelled language is not a trivial task-Patterns of errors in Kiswahili. Reading and Writing, 16(7), 635-666. https://doi.org/10.1007/978-94-009-1041-6_22

Alegria, J., \& Morais, J. (1979). Le développement de l'habileté d'analyse phonétique consciente de la parole et l'apprentissage de la lecture. Archives de Psychologie, 183, 251-270.

Alegria, J., Pignot, E., \& Morais, J. (1982). Phonetic analysis of speech and memory codes in beginning readers. Memory and Cognition, 10(5), 451-456. https://doi.org/10.3758/ BF03197647

Bates, T. C., Castles, A., Luciano, M., Wright, M. J., Coltheart, M., \& Martin, N. G. (2007). Genetic and environmental bases of reading and spelling: A unified genetic dual route model. Reading and Writing, 20(1-2), 147-171. https://doi. org/10.1007/s11145-006-9022-1

Berman, R. A. (1983). On the study of first language acquisition. Language Learning, 33(5): 221-245. https://doi. org/10.1111/j.1467-1770.1984.tb01331.x

Berthoud-Papandropoulou, I. (1980). La réflexion métalinguistique chez l'enfant. Genève: Imprimerie Nationale.

Bloomfield, L. (1933). Language. Chicago, IL: The University of Chicago Press

Booij, G. E. (1987). The reflection of linguistic structure in Dutch spelling. In P. A. Luelsdorff (Ed.), Orthography and 
phonology (pp. 215-224). Amsterdam: John Benjamins. https://doi.org/10.1075/z.29.11boo

Brédart, S., \& Rondal, J.-A. (1982). L'analyse du langage chez l'enfant. Les activités métalinguistiques. Bruxelles: Pierre Mardaga.

Burton-Roberts, N., Carr, P., \& Docherty, G. (2000) (Eds.). Phonological knowledge. Conceptual and empirical issues. Oxford: Oxford University Press.

Çapan, S. (1989). A Linguistic study of reading and writing disorders in Turkish, an agglutinative language. In P. G. Aaron \& R. M. Joshi (Eds.), Reading and writing disorders in different orthographic systems (pp. 191-202). Dordrecht: Kluwer. https://doi.org/10.1007/978-94-009-1041-6 11

Cazden, C. (1976). Play with language and meta-linguistic awareness. In A. J. Bruner \& K. Sylva (Eds.), Play: Its role in development and evolution (pp. 603-608) New York: Basic Books.

Chomsky, N. (1957). Syntactic structures. The Hague: Mouton.

Chomsky, N. (1965). Aspects of the theory of syntax. Cambridge, MA: The MIT Press.

Chomsky, N. (1975). Reflections on language. New York: Pantheon Books.

Chomsky, N. (1978). On the biological basis of language capacities. In G. A. Miller \& E. Lenneberg (Eds.), Psychology and biology of language and thought. Essays in honor of Eric Lenneberg (pp. 199-220). New York: Academic Press.

Chomsky, N. (1986). Knowledge of language. Its nature, origin and use. New York: Praeger.

Chomsky, N. (1988). Language and problems of knowledge. The Managua lectures. Cambridge, MA: The MIT Press.

Chomsky, N., \& Halle, M. (1968). The sound pattern of English. New York: Harper \& Row.

Content, A. (1985). Le développement de l'habileté d'analyse phonétique de la parole. L'Année psychologique, 85(1), 73-99. https://doi.org/10.3406/psy.1985.29069

Coulmas, F. (2003). Writing systems. An introduction to their linguistic analysis. Cambridge: Cambridge University Press.

Crain, S., \& Fodor, J. D. (1993). Competence and performance in child's language. In E. Dromi (Ed.), Language and cognition: A developmental perspective (pp. 141-171). Norwood, NJ: Ablex.

Daniels, P. T. (1992). The syllabic origin of writing and the segmental origin of the alphabet. In P. A. Downing, S. D. Lima, \& M. Noonan (Eds.), The linguistics of literacy (pp. 83-110). Amsterdam: John Benjamins. https://doi. org/10.1075/tsl.21.10dan

Daniels, P. T. (2010a). Writing systems. In M. Aronoff \& J. Rees-Miller (Eds.), The handbook of linguistics (pp. 43-80). Oxford: Blackwell.

Daniels, P. T. (2010b). Writing in the world and linguistics. Papers of the Berkeley Linguistics Society, 36, pp. 61-90. https://doi.org/10.3765/bls.v36i1.3903

Dijkstra, T., Grainger, J., \& van Heuven, W. J. B. (1999). Recognition of cognates and interlingual homographs: The neglected role of phonology. Journal of Memory and Language, 41(4), 496-518. https://doi.org/10.1006/ jmla.1999.2654

Dijkstra, T., Timmermans, M. \& Schriefers, H. (2000). On being blinded by your other language: Effects of task demands on interlingual homograph recognition. Journal of Memory and Language, 42(4), 445-464. https://doi. org/10.1006/jmla.1999.2697

Edwards, H. T., \& Kirkpatrick, A. G. (1999). Metalinguistic awareness in children: A developmental progression. Journal of Psycholinguistic Research, 28(4), 313-329. https://doi.org/10.1023/A:1023275214000

Eysenck, M. W. (1994). Perspectives on psychology. Hove: Psychology Press.

Faber, A. (1990). Phonemic segmentation as epiphenomenon: Evidence from the history of alphabetic writing. Haskins Laboratories Status Report on Speech Research. SR-101/102, 28-40.

Ferreiro, E., \& Teberosky, A. (1984). Psicogênese da língua escrita. Porto Alegre RS: Artes Médicas.

Février, J. G. (1984). Histoire de l'écriture. Paris: Payot.

Fijalkow, J. (1982). Langage écrit. In J. A. Rondal \& X. Seron (Eds.), Troubles du langage. Diagnostic et réeducation (pp. 63-81). Bruxelles: Pierre Mardaga.
Foss, D. J., \& Hakes, D. T. (1978). Psycholinguistics. An introduction to the psychology of language. Englewood Cliffs, NJ: Prentice-Hall.

Foster-Cohen, S. H. (1999). An Introduction to child language development. London: Longman.

Frost, R. (1989). Orthography and phonology: The psychological reality of orthographic depth. Haskins Laboratories Status Report on Speech Research. SR-99/100, 162-171.

Frost, R., Repp, B. H., \& Katz, L. (1988). Can speech perception be influenced by simultaneous presentation of print? Journal of Memory of Language, 27(6), 741-755. https:// doi.org/10.1016/0749-596X(88)90018-6

Gelb, I. J. (1952). A study of writing. Chicago, IL: The University of Chicago Press.

Girolami-Boulinier, A., \& Pinto, M. G. (1996). English, French and Portuguese spelling in the 4 th school year. In S. Contento (Ed.), Psycholinguistics as a multidisciplinary connected science. Proceedings of the 4th ISAPL International Congress (pp. 35-40). Cesena/Bologna: Il Ponte Vecchio/ Università degli Studi di Bologna.

Gleason Jr., H. A. (1955). An introduction to descriptive linguistics. New York: Holt, Rinehart and Winston.

Gombert, J. E. (1990). Le développement métalinguistique. Paris: Presses Universitaires de France.

Goswami, U., Ziegler, J. C., Dalton, L., \& Schneider, W. (2003). Nonword reading across orthographies: How flexible is the choice of reading units? Applied Psycholinguistics, 24(2), 235-247. https://doi.org/10.1017/ S0142716403000134

Grainger, J., Spinelli, E., \& Ferrand, L. (2000). Effects of baseword frequency and orthographic neighborhood size in pseudohomophone naming. Journal of Memory and Language, 42(1), 88-102. https://doi.org/10.1006/ jmla.1999.2675

Hallé, P. A., Chéreau, C., \& Segui, J. (2000). Where is the /b/ in "absurde" [apsyrd]? It is in French listeners' minds. Journal of Memory and Language, 43(4), 618-639. https://doi. org/10.1006/jmla.2000.2718

Harris, M. (1992). Language experience and early language development. From input to uptake. Hove: Psychology Press.

Harris, M., \& Giannouli, V. (1999). Learning to read and spell in Greek: The importance of letter knowledge and morphological awareness. In M. Harris \& G. Hatano (Eds.), Learning to read and write. A cross-linguistic perspective (pp. 51-70). Cambridge: Cambridge University Press.

Henriques, I. (2013). A fricativa coronal /S/ em /\#(Ø) SCl em português europeu [PhD Dissertation]. University of Porto, Portugal.

Jared, D. (1997). Spelling-sound consistency affects the naming of high-frequency words. Journal of Memory and Language, 36(4), 505-529. https://doi.org/10.1006/jmla.1997.2496

Jespersen, O. (1924). The philosophy of grammar. London: George Allen \& Unwin.

Kavanagh, J. F. (Ed.). (1991). The language continuum. From infancy to literacy. Parkton, MD: York Press.

Kaye, J. (1992). Do you believe in magic? The story of $\mathrm{s}+\mathrm{C}$ sequences. SOAS Working Papers in Linguistics, 2, 293-313.

Klees, M. (1989). Developmental dyslexia in French language. In P. G. Aaron \& R. M. Joshi (Eds.), Reading and writing disorders in different orthographic systems (pp. 137-142). Dordrecht: Kluwer. https://doi. org/10.1007/978-94-009-1041-6_7

Klima, E. S. (1972). How alphabets might reflect language. In J. F. Kavanagh \& I. G. Mattingly (Eds.), Language by ear and by eye. The relationships between speech and reading (pp. 57-80). Cambridge MA: The MIT Press.

Kohnen, S., Nickels, L., Coltheart, M., Brunsdon, \& R. (2008). Predicting generalization in the training of irregular word spelling: Treating lexical spelling deficits in a child. Cognitive Neuropsychology, 25(3), 343-375. https:// doi.org/10.1080/02643290802003000

Korkeamäki, R.-L. (1997). What can be learned about reading acquisition in the Finnish language. In C. K. Leong \& R. M. Joshi (Eds.), Cross-language studies of learning to read and spell. Phonologic and orthographic processing (pp. 331-359). Dordrecht: Kluwer. https://doi. org/10.1007/978-94-017-1197-5_18 
Kress, G. (2000). Early spelling. Between convention and creativity. London: Routledge.

Leão, D. N. (1576/1983). Ortografia da Língua Portuguesa. Ed. M. L. Carvalhão Buescu. Lisboa: INCM.

Leong, C. K., \& Joshi, R. M. (1997). Relating phonologic and orthographic processing to learning to read and spell. In C. K. Leong \& R. M. Joshi (Eds.), Cross-language studies of learning to read and spell. Phonologic and orthographic processing (pp. 1-29). Dordrecht: Kluwer. https://doi. org/10.1007/978-94-017-1197-5_1

Linell, P. (1982). The written language bias in linguistics. Linköping: Linköping University.

Luelsdorff, P. A. (Ed.). (1987). Orthography and phonology. Amsterdam: John Benjamins. https://doi.org/10. $1075 /$ z. 29

Luelsdorff, P. A. (1991). Developmental orthography. Amsterdam: John Benjamins. https://doi.org/10.1075/z.51

Martinet, A. (1960). Eléments de linguistique générale. Paris: Armand Colin.

Miranda, A. R. M., \& Veloso, J. (2017). Consciência linguística: Aspetos fonológicos. In M. J. Freitas \& A. L. Santos (Eds.), Aquisicão de língua materna e não materna. Questões gerais $e$ dados do português (pp. 439-458). Berlin: Language Science Press.

Morais, J., Alegria, J., \& Content, A. (1987). The relationships between segmental analysis and alphabetic literacy: An interactive view. Cahiers de psychologie cognitive/European Bulletin of Cognitive Psychology, 5, 415-438.

Morais, J., Cary, L., Alegria, J., \& Bertelson, P. (1979). Does awareness of speech as a sequence of phones arise spontaneously? Cognition, 7(4), 323-331. https://doi. org/10.1016/0010-0277(79)90020-9

Morais, J., Kolinsky, R., \&Nakamura, M. (1996). The psychological reality of speech units in Japanese. In T. Otake \& A. Cutler (Eds.), Phonological structure and language processing: Cross-linguistic studies (pp. 203-216). Berlin : Mouton de Gruyter. https://doi. org/10.1515/9783110815825.203

Morchio, B., Ott, M., \& Pesenti, E. (1989). The Italian language: Developmental reading and writing problems. In P. G. Aaron \& R. M. Joshi (Eds.), Reading and writing disorders in different orthographic systems (pp. 143-161). Dordrecht: Kluwer. https://doi.org/10.1007/978-94-009-1041-6 8

Nakamura, M., Kolinsky, R., Spagnoletti, C., \& Morais, J. (1998). Phonemic awareness in alphabetically literate Japanese adults: The influence of the first acquired system. Cahiers de Psychologie Cognitive/Current Psychology of Cognition, 17(2), 417-450.

Olson, D. R. (1993). How writing represents speech. Language \& Communication, 13(1), 1-17. https://doi. org/10.1016/0271-5309(93)90017-H

Peereman, R., \& Content, A. (1997). Orthographic and phonological neighborhoods in naming: Not all neighbors are equally influential in orthographic space. Journal of Memory and Language, 37(3), 382-410. https://doi. org/10.1006/jmla.1997.2516

Perfetti, C. A. (1997). The psycholinguistics of spelling and reading. In C. A. Perfetti, L. Rieben, \& M. Fayol (Eds.), Learning to spell. Research, theory, and practice across languages (pp. 21-38). Mawhaw, NJ: Lawrence Erlbaum. https://doi.org/10.4324/9781410604583

Pinker, S. (1994). The language instinct. London: Penguin Books.

Porpodas, C. D. (1989). The phonological factor in reading and spelling of Greek. In P. G. Aaron \& R. M. Joshi (Eds.), Reading and writing disorders in different orthographic systems (pp. 177-190). Dordrecht: Kluwer. https://doi. org/10.1007/978-94-009-1041-6 10

Pratt, C., \& Grieve, R. (1984). The development of metalinguistic awareness: An introduction. In W. E. Tunmer, C. Pratt \& M. L. Herriman (Eds.), Metalinguistic awareness in children (pp. 2-11). Berlin: Springer. https://doi. org/10.1007/978-3-642-69113-3_1

Read, C. (1978). Children's awareness of language, with emphasis on sound systems. In A. Sinclair, R. J. Jarvella, \& W. J. M. Levelt (Eds.), The child's conception of language (pp. 65-82). Berlin: Springer. https://doi. org/10.1007/978-3-642-67155-5_5
Reitsma, P. (1989). Orthographic memory and learning to read. In P. G. Aaron \& R. M. Joshi (Eds.), Reading and writing disorders in different orthographic systems (pp. 51-73). Dordrecht: Kluwer. https://doi. org/10.1007/978-94-009-1041-6_3

Rogers, H. (2005). Writing systems. A linguistic approach. Oxford: Blackwell.

Saussure, F. (1916). Cours de Linguistique Générale. Edition critique préparée par Tullio de Mauro. Paris: Payot, 1980. [Cited in Coulmas (2003) as Saussure (1959).]

Scliar-Cabral, L., Morais, J., Nepomuceno, L., \& Kolinsky, R. (1997). The awareness of phonemes: So close-so far away. International Journal of Psycholinguistics, 13, 211-240.

Sgall, P. (1987). Towards a theory of phonemic orthography. In P. A. Luelsdorff (Ed.), Orthography and phonology (pp. 1-30). Amsterdam: John Benjamins. https://doi. org/10.1075/z.29.03sga

Snowling, M. J. (1989). Developmental dyslexia: A cognitive developmental perspective. In P. G. Aaron \& R. M. Joshi (Eds.). Reading and writing disorders in different orthographic systems (pp. 1-23). Dordrecht: Kluwer. https://doi. org/10.1007/978-94-009-1041-6 1

Sprenger-Charolles, L., Siegel, L. S., \& Béchennec, D. (1997). Beginning reading and spelling acquisition in French: A longitudinal study. In C. Perfetti, L. Rieben, \& M. Fayol (Eds.), Learning to spell. Research, theory, and practice across languages (pp. 339-359). Mawhaw, NJ: Lawrence Erlbaum.

Suomi, K., \& Ylitalo, R. (2004). On durational correlates of word stress in Finnish. Journal of Phonetics, 32(1), 35-63. https://doi.org/10.1016/S0095-4470(03)00005-6

Taylor, I. (2002). Phonological awareness in Chinese reading. In W. Li, J. S. Gaffney, \& J. L. Packard (Eds.), Chinese children's reading acquisition. Theoretical and pedagogical issues (pp 39-58). Boston, MA: Kluwer. https://doi. org/10.1007/978-1-4615-0859-5_3

Tunmer, W. E., \& Herriman, M. L. (1984). The development of metalinguistic awareness: A conceptual overview. In W. E. Tunmer, C. Pratt, \& M. L. Herriman (Eds.). Metalinguistic awareness in children. Theory, research, and implications (pp. 12-35). Berlin: Springer. https://doi. org/10.1007/978-3-642-69113-3 2

Tunmer, W. E., Pratt, C., \& Herriman, M. (1984). Preface. In W. E. Tunmer, C. Pratt, \& M. L. Herriman (Eds.), Metalinguistic awareness in children. Theory, research, and implications (pp. vii-viii). Berlin: Springer. https://doi. org/10.1007/978-3-642-69113-3

Valle-Arroyo, F. (1989). Reading errors in Spanish. In P. G. Aaron \& R. M. Joshi (Eds.), Reading and writing disorders in different orthographic systems (pp. 163-175). Dordrecht: Kluwer. https://doi.org/ 10.1007/978-94-009-1041-6 9

Valtin, R. (1989). Dyslexia in the German language. In P. G. Aaron \& R. M. Joshi (Eds Reading and writing disorders in different orthographic systems (pp. 119-135). Dordrecht: Kluwer. https://doi.org/10.1007/978-94-009-1041-6 6.

Van Kleeck, A. (1982). The emergence of linguistic awareness: A cognitive framework. Merrill-Palmer Quarterly, 28(2), $237-265$.

Veloso, J. (2005). A língua na escrita e a escrita da língua. Algumas considerações gerais sobre transparência e opacidade fonémicas na escrita do português e outras questões. Da Investigacão às Práticas. Estudos de Natureza Educacional 6(1), 49-69.

Veloso, J. (2007). Da influência do conhecimento ortográfico sobre o conhecimento fonológico. Estudo longitudinal de um grupo de crianças falantes nativas do português europeu. München: Lincom Europa.

Veloso, J. (2010). Primeiras produções escritas e operações metafonológicas explícitas como pistas para a caracterização inferencial do conhecimento fonológico. Cadernos de Educação, 35, 19-50.

Villiers, J. G., \& Villiers, P. A. (1978). Language acquisition. Cambridge, MA: Harvard University Press.

Wimmer, H., \& Landerl, K. (1997). How learning to spell German differs from learning to spell English. In C. A. 
Perfetti, L. Rieben, \& M. Fayol (Eds.), Learning to spell. Research, theory, and practice across languages (pp. 81-96). Mawhaw, NJ: Lawrence Erlbaum.

Wimmer, H., Landerl, K., \& Frith, U. (1999). Learning to read German: Normal and impaired acquisition. In $\mathrm{M}$. Harris \& G. Hatano (Eds.), Learning to read and write.
A cross-linguistic perspective (pp. 34-50). Cambridge: Cambridge University Press.

Zuck, D. (1996). Inhibition with orthographically similar lowfrequency word targets preceded by high-frequency primes. Journal of Psycholinguistic Research, 25(6), 643-658. https://doi.org/10.1007/BF01712414 